\title{
Can cancer at work be regulated?
}

In the century and a half since cancer of the scrotum among chimney sweeps was first recognized as an occupational disease, interest in (and anxiety about) occupational cancer has grown steadily. Since the Second World War, there has been continuing concern for the health of those occupationally exposed to ionizing radiation, and all governments have introduced regulations intended to limit the exposure of workpeople and thus the risk of overt disease. More recently, attention has turned to the occupational risks of the exposure of workpeople (and also the general population) to industrial chemicals. In the United States, the passage of the Occupational Health and Safety at Work Act in 1970 led to the creation of two separate organizations with responsibility in the field - the National Institute for Occupational Safety and Health (whose function is research and evaluation) and the Occupational Safety and Health Administration (which can regulate industrial practice). In Britain, legislation on the American model led in 1974 to the creation of the Health and Safety Executive and its supervisory commission. For the past three years, the Health and Safety Executive has been struggling with a regulation requiring the notification of new chemical substances (see Nature $16 \mathrm{July}$, p.190) but even now is unlikely to meet the deadline of 18 September decreed by the European Commission.

Nobody should be surprised. European administrations' attempts to restrict the introduction of potentially hazardous chemicals are the analogues of the regulations enshrined in the Toxic Substances Control Act of 1976, which took the best part of six years to emerge from an embattled Congress in the United States. There are several contentious issues. Chemical companies resent the cost of subjecting all new chemicals to a battery of short and long-term toxicity tests - and, with more reason, fear that too wooden an exercise of regulatory powers by the responsible agencies may deprive them of the use of a valuable intermediate even when effective precautions may be taken. A more serious difficulty, shown up by the muddled division of responsibility in the United States between the Environmental Protection Agency (responsible for the administration of the Toxic Substances Control Act) and the Occupational Safety and Health Administration is that of making sensible arrangements for the protection of the public at large, and of people occupationally exposed to larger concentrations of the same materials.

In Britain, as earlier in the United States, a further complication has arisen - the interest of the trades unions in the design of the regulations and in their administration. This development is entirely to be welcomed. Even the most diehard opponents of organized labour would agree that unions are better occupied in the protection of the health of their members than in some of the other things they do. Industry as a whole, and the community at large, can only benefit from a proper understanding by its workpeople of the occupational risks they are asked to run - and from their informed consent that risks of some magnitude, ideally small but probably not identical with zero, should be run. The time that might now be spent in Britain by the Health and Safety Executive on reconciling the interests of the trades unions and the chemical manufacturers would be well worthwhile.

Unfortunately, good sense is in danger of being overtaken by events. The Health and Safety Executive, applauded ever since its creation as a novel and autonomous entity within the British constitution, is much in need of the safety valve of which its special place deprives it - an expression of a range of prejudiced opinion in the House of Commons. (Is the House of Lords too busy to oblige?) The second draft of its regulations on the notification of new substances is indeed needlessly onerous, too cut and dried, and the executive should take the time to produce a third, whatever they say in Brussels. The trouble, now, is that the executive has to watch out not only for the European Commission but for $\mathrm{Mr}$ Clive Jenkins, the secretary of the trade union called the Association of Scientific, Technical and Managerial Staffs.

Mr Jenkins's union has in the past few years taken a close and often constructive interest in problems of occupational health and safety. More than a year ago, it produced an arresting (if controversial) document about the occupational hazards of new chemicals. Ten days ago, $\mathrm{Mr}$ Jenkins issued a lengthy commentary on the second draft of the Health and Safety Executive's proposed notification regulations and made some cogent points. Chemical companies are indeed too defensive of their superficial financial interests, and too unwilling to let independent outsiders enquire into their affairs. The costs of complying with regulations have been systematically (that is, consistently) exaggerated. And so on. He erred only in the most rudimentary way - by supposing that there is some state of grace in which occupational risks are absolutely avoidable. His problem, and the executive's, is rather how to strike a balance between the possibly carcinogenic risk of a novel chemical and the possibility that somebody, or some group, will be out of work. Who will persuade whom of that?

\section{Damming estuaries}

The hope that there might be some other way - any other way - of generating electricity than those now used is likely to be widely paraded in the weeks ahead. The United Nations conference on alternative energy sources due to open in Nairobi next week will be an obvious forum (see also page $x x x$ ). And nobody should deride the innocent declarations of faith in windmills, water-wheels or wood (now called biomass) that there will be. There are unfortunately still too many circumstances, in still too many developing countries, in which any way of generating a modicum of mechanical power from some indigenous source is much needed. But those who assemble in Nairobi should also take to heart the message hidden in last week's report of Sir Hermann Bondi's study of the feasibility of an electricity-generating barrage across the Severn estuary, between England and Wales (see Nature $30 \mathrm{July}, \mathrm{p} .401$ ). The conclusion of this thorough piece of work is that if British taxpayers want the kinds of benefits that a barrage across the Severn estuary would provide, they would be best advised to build nuclear power stations and not a dam.

The argument is simple but instructive. A dam across an estuary can be used to generate electricity in several obvious ways - by letting the incoming tide drive turbines in a dam, by letting water impounded at high tide run back through turbines on the ebb tide or (as in the scheme operated by Electricite de France on the estuary of the Rance since 1966) arranging that water in an estuary will drive turbines at both the ebb and flood tides. The amounts of energy that can in principle be won from such schemes are huge the Bondi committee estimated that even the most modest of all possible dams across the Severn could yield 13 TWh of electricity, something like six per cent of present electricity demand in the United Kingdom, roughly the amount of electricity that would be 